\title{
Influence of Leather Fiber on Modulus of Elasticity in Bending Test and of Bend Strength of Particleboards
}

\author{
Renato Cardoso de Oliveira ${ }^{a}$, Rodrigo Andraus Bispo ${ }^{a}$ (1), Mariana Ferreira Trevisan ${ }^{a}$ (), \\ Caroline Graminha Gilio ${ }^{a}$, Felipe Reis Rodrigues ${ }^{a}$, Sérgio Augusto Mello da Silva ${ }^{a}$ \\ ${ }^{a}$ Universidade Estadual Paulista Júlio de Mesquita Filho Campus de Ilha Solteira, \\ Alameda Bahia, 550 - Zona Norte, Ilha Solteira, SP, Brasil.
}

Received: June 15, 2021; Revised: June 15, 2021; Accepted: August 19, 2021

\begin{abstract}
The society's development provides consequences such as the increasing generation of industrial waste. In the city of Franca, São Paulo's inland city, there are footwear industries that generate a large amount of leather waste during their production process. In most cases, there's no use of this waste and they're disposed of in landfills. A reuse alternative is the production of particleboards used in construction sectors. Therefore, one of the biggest challenges is the use of this leather waste adding value to the product and enabling the production of sustainable material. This work proposes the production of particleboards from Eucalyptus wood and leather fibers using castor oil polyurethane adhesive. In addition, the assessment of the leather fiber influence on modulus of rupture and elasticity obtained from a static bending test. The study investigated the proportion of $10 \%, 25 \%$ e $50 \%$ leather waste in relation to Eucalyptus particles and $10 \%$ castor oil polyurethane adhesive. The mechanical performance of the panels was evaluated based on ABNT NBR 14810-1 and 2 (2013; 2018). The results allowed us to ascertain that the incorporation of $10 \%$ leather waste in particleboard rated them, according to NBR 14810-1 and 2 (2013; 2018), as structural panels of type P4 for use in dry conditions.
\end{abstract}

Keywords: Particleboard, Leather, Eucalyptus.

\section{INTRODUCTION}

Particleboards are structures manufactured in different stages of wood disintegration or in wood veneers, which are bonded by means of specific resins. These structures replace the use of solid wood in different areas, such as floor and furniture manufacturing ${ }^{1}$.

Particleboards are obtained by agglomerating of small fragments of wood with the aid of binders. Due to this mode of production, it is possible to take advantage of self-binding properties of wood as it is a lignocellulosic material ${ }^{2}$.

These structures are seen as a way to increase the use of materials from forest production. Since it can give more noble destination to woods of lower dimensions or quality ${ }^{3}$. The scarcity of raw material supply for wood-based panels has triggered the development of studies in the scientific field. These works are generally intended to seek diversity in sources of lignocellulosic materials to produce particleboards ${ }^{4-7}$.

Particles by sugarcane, malva fibre from amazon and, wood of pinus taeda was researched ${ }^{4}$ to made sandwich particleboard. Medium density particleboards - MDP multi layers was produced with coir and sisal fibers in proportions of $0,10 \%$ and $20 \%$ in relation of particles of wood eucalyptus in the core of the particleboards ${ }^{5}$

Other agro-industrial solid wastes of lignocellulosic origin like olive stones was used to produce particleboards ${ }^{6}$ showing several environmental and economic benefits. Macadamia nut carpel, coffee husk and papaya stem gave

*e-mail: rodrigoandrausbispo@gmail.com rise to particleboards associated with eucalyptus particles in proportions of $10 \%, 20 \%$ and $30 \%$ respectively $^{7}$

Parallel to the fact, the leather sector in the city of Franca SP generates on average 160 tons of waste per day, about $11.43 \%$ of national production ${ }^{8}$ This waste may come from the processing of rawhide or leather remnants used in footwear industries. All these waste materials are usually destined for landfills without any use.

According to a report of Brazilian Association of Footwear Industries ${ }^{9}$, the Brazilian footwear sector is made up of approximately 7,700 companies, where $66.1 \%$ are concentrated in the states of Rio Grande do Sul and São Paulo. This sector in 2016 generated around 286.7 thousand jobs and produced about 954 million pairs of shoes, ensuring the third place in the ranking of world producers. In the same year, the sector exported 125.6 million pairs of shoes, exporting large quantities of leather shoes, a raw material that has long been and is still widely used as the main constituent in shoe manufacturing.

Regarding the distribution of footwear companies, there is a geographic concentration in certain regions of Brazil, which is Franca, Birigui and Jaú the main representative centers of the State of São Paulo. Solely the pole of Franca-SP represents $36.1 \%$ of the state's production.

Several researches strive to use leather waste in production processes, with the most diverse purposes, with the aim to mitigating the damage caused to the environment with incorrect disposal, valorize the waste and the possibility 
of adding characteristics or even improving properties the products $^{10-12}$ including the use of waste leather in the building sector ${ }^{13}$ and leather shavings in Portland cement mortars ${ }^{14}$

Given this cenary, highlight the need to apply new byproducts for the manufacture of particleboards. Therefore, this work proposes the study of leather fibers, discarded by footwear industries in the city of Franca-SP, to produce particleboards.

The main of this paper is the production and evaluation of particleboards using eucalyptus particles and leather fibers from the disposal of footwear industries in the city of FrancaSP and using as a binder castor oil-derived polyurethane resin. The evaluation of the particleboards was performed based on NBR $14810-1$ and $2(2013 ; 2018)^{15,16}$ to verify use.

\section{MATERIALS AND METHODS}

\subsection{Materials}

Eucalyptus wood specie particles were used to produce particleboards, which its pieces were obtained from a lumber yard company in the region of Ilha Solteira city, state of São Paulo. The leather fibers used were a donation from the footwear industry called "Newborn" located in the city of Franca, state of São Paulo. Figure 1 illustrates general aspects of the leather particles used in the panels.

Castor oil polyurethane adhesive was used as a resin to agglutinate the particle. This adhesive was donated by a Brazilian company called located in Aguaí city from São Paulo region. This product consists of two components, which one of them the prepolymer composed of petroleum-derived and the polyol, derived from castor oil.

\subsection{Particles Preparation}

Eucalyptus wood pieces were first processed in a thinning planer and the final particles were grinded in a knife-mill. This step aims to obtaining particles close to the ideal grain size of the panels, which is 2 to $6 \mathrm{~mm}$.

A granulometric analysis was performed in an electric sieve with vibratory system. This step was performed using this mesh sieves set: $12.59 .52 ; 6.36 ; 4.36 ; 2.36$ (mm), as shown in Figure 2. All material retained in the 2.36 and $4.36 \mathrm{~mm}$ sieves was used as raw material for the panels manufacturing. The purpose of selecting this size range facilitates particleboards compaction and increases particle adhesion.

This step was also intended to perform the grain size analysis of eucalyptus particles. It was proposed to adapt, for wood particles, the test of ABNT NBR NM 248: 2003 "Aggregates - Determination of particle size composition"17 Two mass samples of $50 \mathrm{~g}$ were sieved using the SOLOTEST equipment, shown in Figure 3 Subsequently, the fineness modulus was calculated and evaluated. the particle size curves plotted.

After selecting the particles to be used in the panels, the moisture content was calculated based on Equation 1, which $\mathrm{U}$ is moisture content express in percentage, $\mathrm{MU}$ is wet mass expressed in grams, MS is dry mass expressed in grams. If the particles had a moisture value in the range of 10 to $12 \%$, the panel production process would be continued.
If not, the amount of water to be added should be calculated to reach a value in the range of 10 to $12 \%$.

$U=(M U-M S) / M S \times 100$

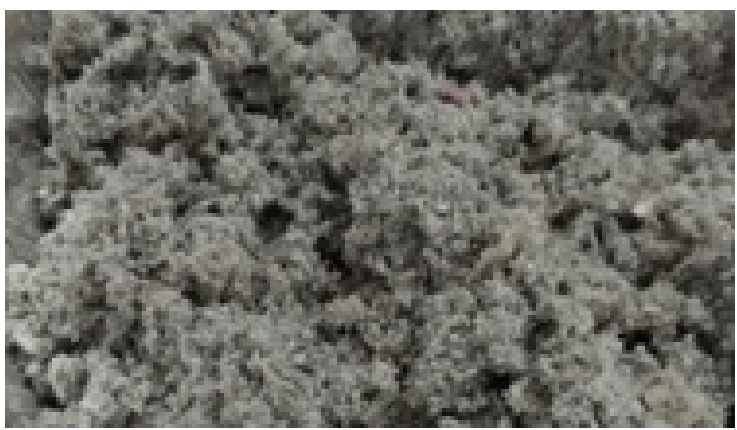

Figure 1. Leather particles used in particleboards.

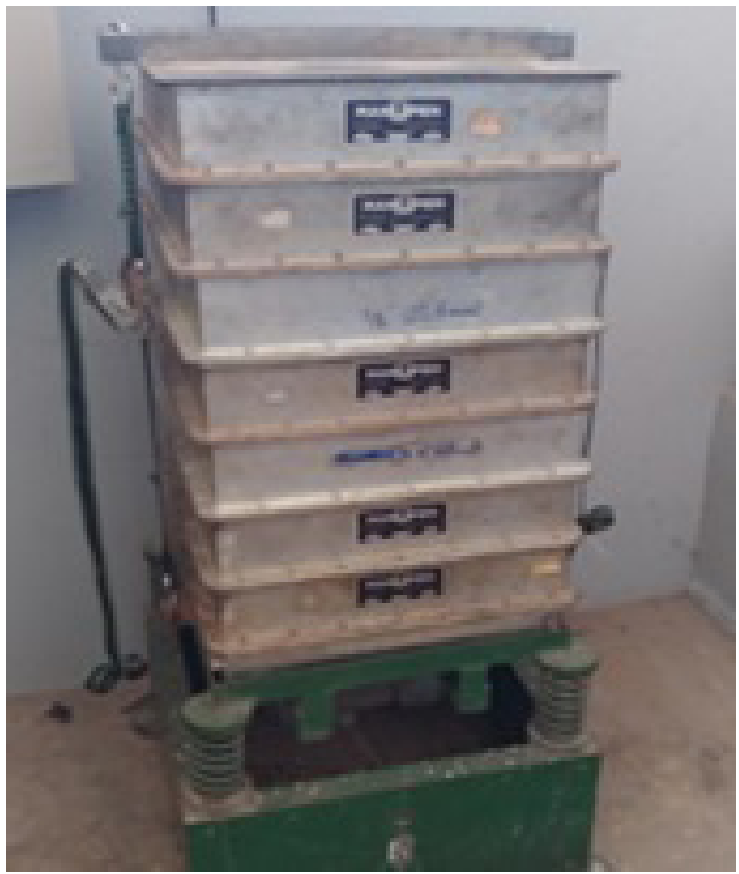

Figure 2. Mesh sieves set.

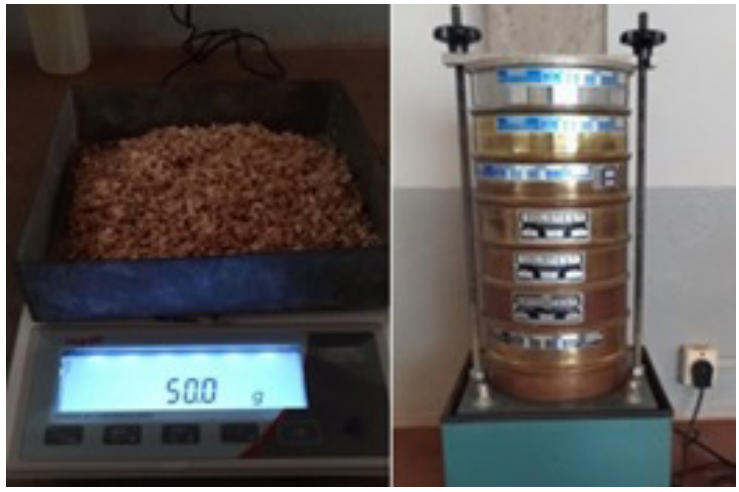

Figure 3. Particle size composition of wood particles. 


\subsection{Manufacture of the particleboards}

The treatments proposed in this research called: (T1, T2 e T3) are presented in Table 1 below.

In order to homogenize the resin to the particles, two steps were required, at first the polyol was mixed and then the prepolymer. Both homogenization steps were performed manually and then mechanically, with the aid of a concrete mixer. After that, Figure 4 shows a pre-pressing of the particle-mattress by using a wood shape with $35 \times 35 \mathrm{~cm}$ dimensions.

A $0.2 \mathrm{~mm}$ thick aluminum foil was placed under the shape to prevent the particle-mattress from adhering to the hydraulic press plates. After pre-pressing, particleboards were compacted in a semi-automatic press for two intervals of 5

Table 1 - Proposed treatments to production the particleboards.

\begin{tabular}{cccc}
\hline Treatments & $\begin{array}{c}\text { Leather fiber } \\
(\%)\end{array}$ & $\begin{array}{c}\text { Eucalyptus } \\
(\%)\end{array}$ & Resin (\%) \\
\hline T1 & 10 & 90 & 10 \\
\hline $\mathrm{T} 2$ & 25 & 75 & 10 \\
\hline $\mathrm{T} 3$ & 50 & 50 & 10 \\
\hline
\end{tabular}

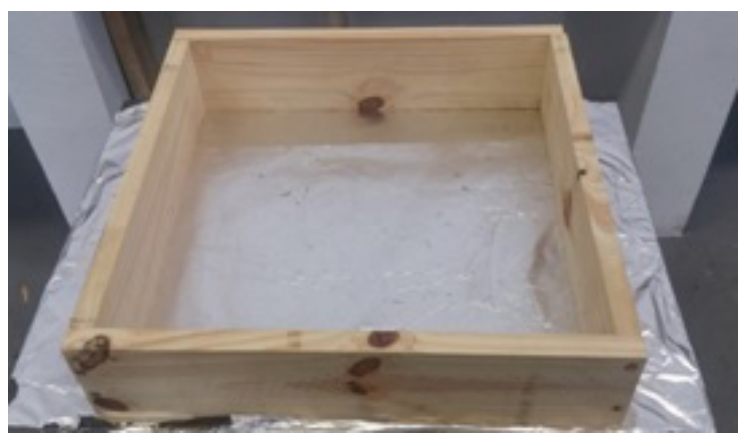

Figure 4. particle-mattress pre-pressing. min with a 30 second relief between them at temperature and pressure $100^{\circ} \mathrm{C}$ and 70 tons.

After that, particleboards were conditioned for $72 \mathrm{~h}$ for stabilization with external environment. Particleboards were measured and squared then with a disk saw according to the dimensions required by ABNT NBR 14810-1 and 2: 2013 $3^{15,16}$.

The specimens squared were submitted to physical tests: Thickness swelling (I), Water absorption (A), Moisture Content (U), Density (D); and mechanical tests: Modulus of rupture in static bending test (MOR), Modulus of elasticity in static bending test (MOE) according to ABNT NBR 14810-1 and 2: $2013^{15,16}$.

\section{RESULT AND DISCUSSION}

\subsection{Particle size composition and moisture content of eucalyptus particles}

The particle size analysis was performed in order to produce particleboards within the appropriate particle size range, according to the literature, Figure 5 shows the analysis graph.

The fineness modulus resulted in $4.83 \mathrm{~mm}$, meaning that the average particle size of the eucalyptus residue is close to this value. It was observed that $78.3 \%$ of the particles were retained in the $2.38 \mathrm{~mm}$ thick sieve, that is, most of the material is above this value and below than the immediately larger thickness sieve, which is the opening $4.76 \mathrm{~mm}$.

The moisture content tests of the particles were performed, and the average moisture contents were in the range of 10 to $12 \%$, so the panel production process could be continued.

\subsection{Physical Testing}

The density of the particleboards is very important and may be related to the results of the other tests, both physical and mechanical. Table 2 shows the average density percentage

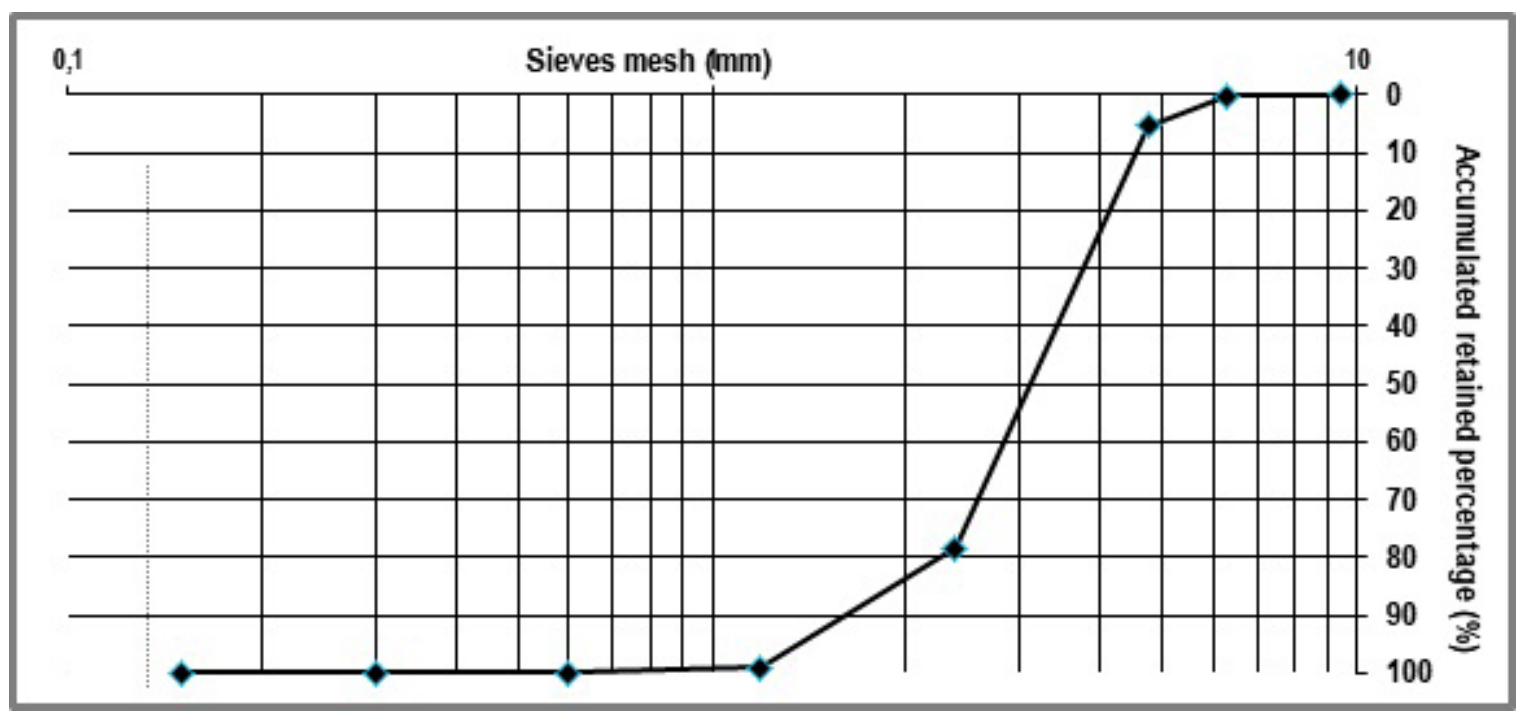

Figure 5. Result of eucalyptus particle size test. 
results and the highest percent density change was - 7.06, a value close to that defined by the standard, but higher.

Moisture levels may influence the compaction of the panel as well as indicate possible error in the test if the indicated value for the resin is not followed. Table 3 shows the average moisture, standard deviation results and the value required by the standard. The specimen's average moisture was in accordance with the parameters established by the current standard. Figure $6 \mathrm{~b}$ shows the aspects of the specimens after 24 hours at $100^{\circ} \mathrm{C}$.

The thickness swelling and water absorption tests are very important to check the possibility of using the panels in wet conditions. Thickness swelling is the result of measuring the specimen's thickness after immersion in water, and absorption is the water's mass absorbed after that. Table 4 shows the results of the specimens' average swelling, standard deviation results and the value required by the standard. Only the T1 treatment (10\% leather fiber) met the normative standards, while the T2 and T3 treatments (25\% and 50\% leather fiber respectively) exceeded the upper limit.

Since the absorption test is not in force in standard NBR $14810-1$ and $2^{15,16}(2013 ; 2018)$, the results of the absorption test of the present work were compared with the

Table 2. Table of average density, highest percent density change and value required by the standard.

\begin{tabular}{|c|c|c|c|}
\hline Treatments & $\begin{array}{c}\text { Average } \\
\text { density } \\
\left(\mathrm{kg} / \mathrm{m}^{3}\right)\end{array}$ & $\begin{array}{c}\text { Highest } \\
\text { Percent } \\
\text { Density } \\
\text { Change: D\% } \\
(\%)\end{array}$ & $\begin{array}{c}\text { NBR 14810-1 } \\
\text { and } 2(2013 ; \\
2018)^{15,16}\end{array}$ \\
\hline $\mathrm{T} 1$ & 952.07 & -7.06 & \multirow{3}{*}{ $\pm 7 \%$} \\
\hline $\mathrm{T} 2$ & 857.61 & +6.02 & \\
\hline T3 & 924.37 & -6.08 & \\
\hline
\end{tabular}

Table 3. Average specimen moisture, standard deviation and value required by the standard.

\begin{tabular}{cccc}
\hline Treatments & $\begin{array}{c}\text { Average } \\
\text { moisture (\%) }\end{array}$ & $\begin{array}{c}\text { Standard } \\
\text { Deviation (\%) }\end{array}$ & $\begin{array}{c}\text { NBR 14810-1 } \\
\text { and 2 (2013; } \\
2018)^{15,16}\end{array}$ \\
\cline { 1 - 3 } T1 & 10.46 & 0.313 & \\
\cline { 1 - 3 } T2 & 8.43 & 0.198 & \\
\cline { 1 - 3 } T3 & 7.95 & 0.211 & \\
\hline
\end{tabular}

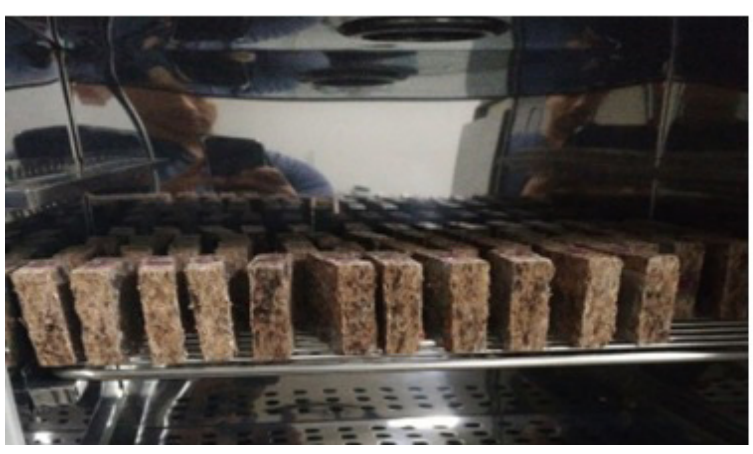

standard DIN ${ }^{18}$ (1961), setting the value of $15 \%$ maximum absorption after 24 hours of immersion. The absorption results obtained are shown in Table 5. As in the thickness swelling test, the gradual increase in the concentration of leather fibers culminated in not meeting the upper limit of water absorption. Only T1 treatment met this verification.

\subsection{Mechanical Testing}

Table 6 shows the results of the average modulus of rupture and the standard values established for non-structural and structural panels. According to the tests performed, the value reached for the T1 treatment was greater than $16 \mathrm{MPa}$, thus classifying as a structural panel. Treatments with $25 \%$ and $50 \%$ of leather fiber did not even meet the standards for non-structural panels.

Table 4. Average swelling of the test specimens, standard deviation and value required by the standard.

\begin{tabular}{cccc}
\hline Treatments & $\begin{array}{c}\text { Avarege } \\
\text { swelling (\%) }\end{array}$ & $\begin{array}{c}\text { Standard } \\
\text { Deviation (\%) }\end{array}$ & $\begin{array}{c}\text { NBR 14810-1 } \\
\text { and 2(2013; } \\
2018)^{15,16}\end{array}$ \\
\cline { 1 - 3 } T1 & 6.98 & 2.22 & \\
\cline { 1 - 3 } T2 & 20.15 & 3.29 & \multirow{2}{*}{$18 \%$} \\
\cline { 1 - 3 } T3 & 26.79 & 2.55 & \\
\hline
\end{tabular}

Table 5. Average absorption of the specimens

\begin{tabular}{cccc}
\hline Treatments & $\begin{array}{c}\text { Average } \\
\text { absorption } \\
(\%)\end{array}$ & $\begin{array}{c}\text { Standard } \\
\text { Deviation (\%) }\end{array}$ & $\begin{array}{c}\text { DIN 68 761 } \\
(1961)^{18}\end{array}$ \\
\cline { 1 - 3 } T1 & 10.43 & 2.29 & \multirow{2}{*}{$15 \%$} \\
\cline { 1 - 3 } T2 & 35.00 & 2.65 & \\
\hline T3 & 34.86 & 4.45 & \\
\hline
\end{tabular}

Table 6. Average modulus of rupture and classification.

\begin{tabular}{|c|c|c|c|}
\hline Treatments & $\begin{array}{c}\text { Average MOR } \\
(\mathrm{MPa})\end{array}$ & $\begin{array}{c}\text { Standard } \\
\text { Deviation (\%) }\end{array}$ & $\begin{array}{c}\text { NBR 14810-1 } \\
\text { and } 2(2013 ; \\
2018)^{15,16}\end{array}$ \\
\hline $\mathrm{T} 1$ & 17.98 & 3.47 & $11 \mathrm{MPa}$ for \\
\hline $\mathrm{T} 2$ & 9.30 & 1.48 & non-structural \\
\hline T3 & 11.03 & 1.83 & $\begin{array}{l}\text { 16MPa for } \\
\text { structural } \\
\text { panels. }\end{array}$ \\
\hline
\end{tabular}

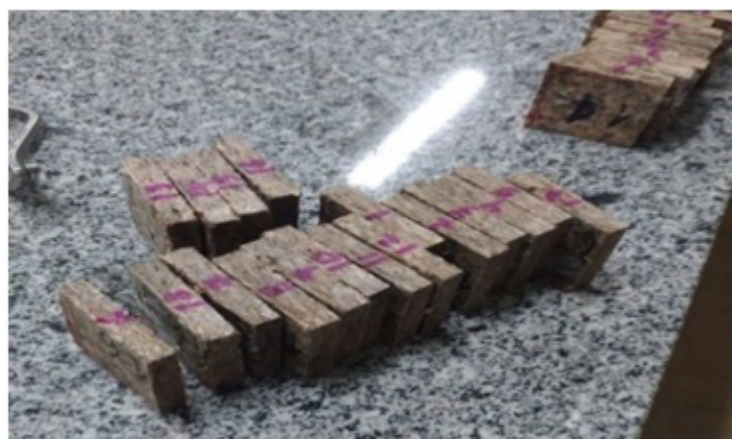

Figure 6. Aspects of specimens (a) Specimes at $100^{\circ} \mathrm{C}$; (b) Specimes after $24 \mathrm{~h}$ at $100^{\circ} \mathrm{C}$ 
Table 7. Average modulus of elasticity and classification

\begin{tabular}{cccc}
\hline Treatments & $\begin{array}{c}\text { Average MOE } \\
\text { (MPa) }\end{array}$ & $\begin{array}{c}\text { Standard } \\
\text { Deviation (\%) }\end{array}$ & $\begin{array}{c}\text { NBR14810-1 } \\
\text { and 2 }(2013 ; \\
2018)^{15,16}\end{array}$ \\
\cline { 1 - 3 } T1 & 2649.025 & 257.544 & $\begin{array}{c}1800 \text { Mpa for } \\
\text { non-structural } \\
\text { panels, 2300 } \\
\text { MPa for } \\
\text { T2 }\end{array}$ structural $^{\text {panels. }}$ \\
\hline
\end{tabular}

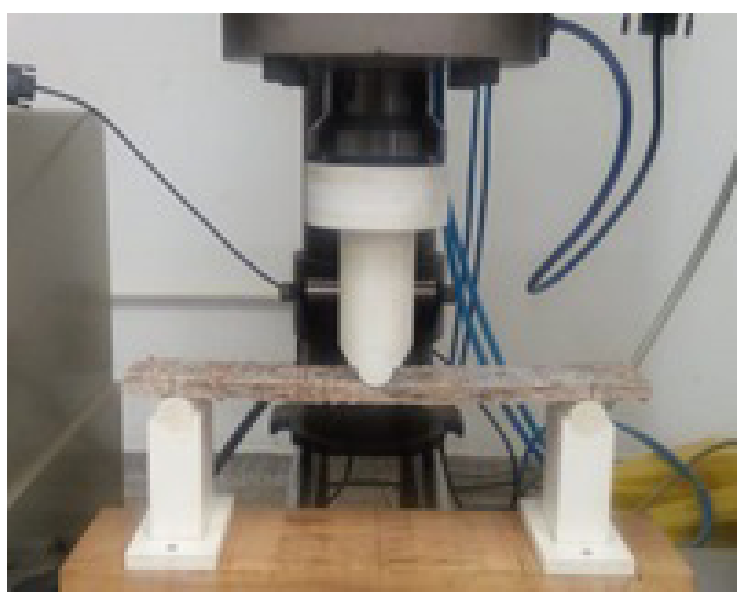

Figure 7. Static bending test.

Table 7 shows the modulus of elasticity results, the values obtained classify the treatment $\mathrm{T} 1$ as structural as well. Treatments T2 and T3 did not meet the lower limit for structural uso, however, the treatment with $50 \%$ of leather fiber was classified for non-structural use, according to this test. Figure 7 shows the static bending test performed at the laboratory of Unesp Ilha Solteira city, state of São Paulo.

\section{CONCLUSION}

The incorporation of $10 \%$ leather waste was interesting, the physical and mechanical results were satisfactory, meeting all the normative requirements. For this treatment, the highest rating achieved was structural panel for use in dry conditions, type P4, according to brazilian standard NBR $14810-1$ and $2^{15,16}(2013 ; 2018)$. It is noteworthy that mean static bendin strength results of $17.98 \mathrm{MPa}$

were obtained, that is, in the same order of magnitude as the minimum value of $18 \mathrm{MPa}$ recommended for P5 type panels (structural panel for use in wet conditions), however, all other properties obtained results higher than the minimum required by the standard for classification for a panel of type P5.

Particleboards produced with $90 \%$ eucalyptus and $10 \%$ leather waste and $10 \%$ of castor-oil present values within the required standard and potential for use in industrial and commercial areas.

The increase in the concentration of leather fiber in relation of eucalyptus contributed to the decrease in the results physical and mechanical tests, disqualifying the panels produced in accordance with the Brazilian standard.

\section{ACKNOWLEDGEMENTS}

The authors gratefully acknowledge the financial support provide by CAPES - Coordenação de Aperfeiçoamento de Pessoal de Nível Superior.

\section{REFERENCES}

1. BNDES: Banco Nacional de Desenvolvimento Econômico e Social. Painéis de madeira reconstituída [Internet]. 2008 [cited 2018 May 15]. Available from: http://www.bndes.gov.br/

2. Lara Palma HA, Ballarin AW. Propriedades de contração na madeira juvenil e adulta de Pinus taeda L. Sci For. 2003;(64):1322.

3. Guimarães JB Jr. Painéis de madeira de eucalipto: estudo de caso de espécies e procedências [dissertação]. Lavras (MG): Universidade Federal de Lavras; 2008. 95 p.

4. Silva MR, Pinheiro RV, Christoforo AL, Panzera TH, Lahr FAR. Hybrid sandwich particleboard made with sugarcane, pínus taeda thermally treated and malva fibre from amazon. Mater Res. 2018;21(1)

5. Mesquita RGA, Marconcini JM, Sanadi AR, César AAS, Tonoli GHD, Venås TM, et al. Coir and sisal fibers as fillers in the production of eucalyptus Medium Density Particleboards - MDP. Mater Res. 2016;19(6)

6. Farag E, Alshebani M, Elhrari W, Klash A, Shebani A. Production of particleboard using olive stone waste for interior design. J Build Eng. 2020;29:101119.

7. Martins RSF, Gonçalves SG, Segundinho PGA, Lelis RCC, Paes JB, Lopez YM, et al. Investigations of agro-industrial lignocellulosic wastes in fabrication of particleboard for construction use. J Build Eng. 2021;43:102903.

8. Cultri, CN, Manfrinato, JWS, Renófio, A. Resíduos sólidos do setor coureiro-calçadista e os fundamentos para a produção mais limpa. In: XIII SIMPEP - Simpósio de Engenharia de Produção; 2016 Nov 6-8; Bauru. Bauru, SP: XIII SIMPEP; 2006.

9. Abicalçados: Associação Brasileira das Indústrias de Calçados. Resenha estatística 2017. Novo Hamburgo: Abicalçados; 2017.

10. Teklay A, Gebeyehu G, Getachew T, Yaynshet T, Sastry TP. Conversion of finished leather waste incorporated with plant fibers in to value added consumer products - an effort to minimize solid waste in Ethiopia. Waste Manag. 2017;68:45-55.

11. Yan T, Luo X, Lin X, Yang J. Preparation, characterization and adsorption properties for lead (II) ofalkali-activated porous leather particles. Colloids Surf A Physicochem Eng Asp. 2017;512:7-16.

12. Chojnacka K, Skrzypczak D, Mikula K, Witek-Krowiak A, Izydorczyk G, Kuligowski K, Bandrow P, Kułazynski M. Progress in sustainable technologies of leather wastes valorization as solutions for the circular economy. J Clean Prod. 2021;313:127902.

13. Vidaurre-Arbizu M, Perez-Bou S, Zuazua-Ros A, Martín-Gomez C. From the leather industry to building sector: exploration of potentialapplications of discarded solid wastes. J Clean Prod. 2021;291:125960.

14. Ribeiro DV, Yuan SY, Morelli MR. Effect of chemically treated leather shaving addition on characteristics and microstructure of OPC mortars. Mater Res. 2012;15(1):136-43.

15. ABNT: Associação Brasileira de Normas Técnicas. NBR 14810-1: Chapas de madeira aglomerada: terminologia. Rio de Janeiro: ABNT; 2013.

16. ABNT: Associação Brasileira de Normas Técnicas. NBR 14810-2: Chapas de madeira aglomerada: requisitos. Rio de Janeiro: ABNT; 2018. 
17. ABNT: Associação Brasileira de Normas Técnicas. NBR NM 248: Agregados Determinação da Composição Granulométrica. Rio de Janeiro: ABNT; 2003.
18. DEUTSCHES INSTITUT FÜR NORMUNGE. Testing of wood chipboards-determination of variation in thickness due to moisture. DIN 68761. Berlim: DIN; 1961. 